\title{
CBX2 wt Allele
}

National Cancer Institute

\section{Source}

National Cancer Institute. CBX2 wt Allele. NCI Thesaurus. Code C92497.

Human CBX2 wild-type allele is located in the vicinity of $17 q 25.3$ and is approximately $9 \mathrm{~kb}$ in length. This allele, which encodes chromobox protein homolog 2 protein, is involved in both the repression of transcription and development. Point mutations of the gene are associated with gonadal dysgenesis. 